\title{
CDK1 Gene
}

National Cancer Institute

\section{Source}

National Cancer Institute. CDK1 Gene. NCI Thesaurus. Code C28559.

This gene is involved in the cellular transition from the G1/S phase and from the G2/M phase of the cell cycle. 